\title{
Modern Extremist Groups and the Division of the World: A Critique from an Islamic Perspective
}

\author{
Mohamed Badar ${ }^{a}$ \\ ${ }^{a}$ Professor of Comparative and International Criminal Law and Islamic Law, \\ Northumbria Law School, Northumbria University, Newcastle, U K \\ mohamed.badar@northumbria.ac.uk \\ Masaki Nagatab \\ ${ }^{b}$ Doctoral candidate, Brunel University London, UK \\ mno72779@gmail.com
}

\begin{abstract}
Modern extremist groups have revived the use of certain concepts of Islamic dogma and wilfully misinterpreted them as a means of achieving their own ends. Dae'sh (Islamic State of Iraq and Syria) is the most striking example. They have made declarations of takfir (excommunication) regarding Muslim rulers, maintaining that only Daesh land is a dar al-Islam (abode of Islam) and that other lands are dar al-kufr or harb (abodes of unbelief or war), just as the Khawarij sect believed in the 7 th century CE. They do not employ the concept of hijra (migration) in its traditional, defensive sense, but rather as a means of strengthening their own power by recruiting from around the world and launching military jihads, all in order to 'reclaim' the dar al-kufr and establish an Islamic state. This article examines the evolution of these terms throughout Islamic history, their misinterpretation by extremist groups, and their modern legal status.
\end{abstract}

* This is the second part of a study. The first part appeared in this journal as: Mohamed Badar, Masaki Nagata and Tiphanie Tueni, 'The Radical Application of the Islamist Concept of Takfir', Arab Law Quarterly 31(2) (2017): 134-162. For the third part of the study see Mohamed Badar, 'The Self-Declared Islamic State (Da'esh) and Ius ad Bellum under Islamic International Law', Asian Yearbook for Human Rights and Humanitarian Law 1 (2017); 35-75. 


\section{Keywords}

Dae'sh (ISIs/Is) - dar al-Islam (abode of Islam) - dar al-kufr or harb (abodes of unbelief or war) - hijra (migration) - military jihad

Islam and the concept and practice of jihad are closely entwined. Jihad, both linguistically and as a technical term, means "struggle", and is etymologically related to mujahadah, which also means struggle or contention, and ijtihad, which is the efforts by jurists to arrive at correct judgments in Islamic law. Jihad is perhaps the most well-known 'Islamic' word to non-Muslims, but arguably also the most misunderstood and misinterpreted, even by Muslims themselves. Calls for jihad have been made by many rulers throughout Islam's military history; one of the greatest heroes of the Islamic world, Saladin (d. 590AH/1193CE), called for his subjects to join in a jihad against their enemies. ${ }^{1}$

The modern-day emergence of extremist groups has had a profound effect on the understanding and usage of Islamic dogmas such as jihad and hijra. The claims made by such groups to religious legitimacy is one reason for their success in soliciting funding and attracting believers willing to fight and die in their wars against those who object to their specific understanding of Islam. However, their aims are clearly just as political or ideological as religious, if not more so. Religious justifications are provided in an attempt to legitimise their actions, but these are means to an end; Islamic concepts have been interpreted and utilised, in ways not intended by the Prophet, in an attempt to achieve political goals.

The twin dogmas of jihad and hijra have been used by Muslim leaders from the Prophet onwards, although their usage has continually evolved throughout history. Hijra was used by the Prophet as a means to maintain the coherence of his group of believers and ensure that his fledgling Islamic society was able to defend itself. There were no military jihads in the Prophet's time. However, mediaeval scholars

1 Ibn al-Athir, The Chronicle of Ibn al-Athìr for the Crusading Period from Al-Kämil Fïl-Ta'rīkh, Part 2: The Years 541-589/1146-1193, The Age of Nur al-Din and Saladin, translated by D.S. Richards (Aldershot: Ashgate, 2007), 318; see also, Bahā' al-Dīn Ibn Shaddād, The Rare and Excellent History of Saladin, or, Al-Nawādir al-Sultaniyya Wa'l-Mahasin Al-Yüsufiyya, translated by D.S. Richards (Aldershot: Ashgate, 2002), 72. 
and rulers used hïra and jihad differently, and these usages have further evolved with their re-introduction by modern extremist groups and their joint use with the term takfir (excommunication).

This article illustrates how extremist groups have misinterpreted the Islamic dogmas of hijra and jihad and argues that there is no legitimacy to their modern usage of these terms. There are four sections to the article. In the second, a number of key definitions and original usages are discussed: the Islamic division of the world into dar al-Islam and dar al-harb; hijra; and jihad. The former, the partition of land into separate zones of belief and unbelief, was a device formulated by mediaeval scholars and was deeply influenced by the then prevailing political and social circumstances. Similarly, hijra was not originally an obligation for all Muslims to migrate from dar al-harb to dar al-Islam; the first hijra was a recommendation and furthermore was not an abode of Islam. Finally, jihad began as a purely spiritual term; the Prophet did not equate it with physical hostilities, neither fighting those who did not fight him or seeking to oppress their societies.

In the third section of the article, the use and evolution of these dogmas throughout Islamic history is illustrated. There are a number of cases relating to the undertaking of hijra from dar al-harb to dar al-Islam, but the legitimacy of all have been questioned and remain controversial. Although certain scholars and groups have relied on Shari'a when making their calls for military jihad, there is actually no basis in Shari'a for such campaigns; military jihads are man-made. Scholars of the mediaeval period conflated qital (fighting) with jihad (spiritual war), thus creating a new form of jihad by the sword (military jihad).

Finally, the fourth section of the article discusses the modern usage of hijra and jihad by extremist groups. These terms are no longer used in a spiritual or defensive way, but have become synonymous with wars conducted in order to establish an Islamic state. The calls of modern extremist groups for hijra from dar al-harb to dar al-Islam cannot be legitimised with reference to Shari'a, as the circumstances pertaining at the time of the Prophet's hijra from Mecca to Medina are simply not those pertaining today, and the purpose behind it was very different. Today, hijra are being called for in order to realise certain extremist groups' understanding of an 'Islamic state', based on the belief that hijra is still an obligation for all Muslims. Dae'sh have issued calls for hijra simply to recruit warriors for their military jihad. They have also sought to employ declarations of takfir (excommunication) in combination with military jihad and hijra, also in an attempt to further their ultimately political aims. 
This section will provide fundamental definitions of four key terms: dar alIslam, dar al-harb, hijra and jihad, none of which were originally intended to be used as war-related terms against unbelievers or non-Islamic rulers. Dar alIslam and dar al-harb were expressions used to reflect the mediaeval political and social circumstances that divided Muslims and non-Muslims; neither term is based on Shari'a. Hijra was a word used by the Prophet to refer to his followers' attempts to escape from persecution and establish a new Islamic community. Finally, jihad is used in Shari'a to refer to spiritual war, not to actual fighting.

\subsection{Dar al-Islam and Dar al-harb}

Classical Muslim jurists traditionally divided the world into two abodes, dar al-Islam (the abode of Islam) and dar al-harb (the abode of war) or dar al-kufr (the abode of unbelief). According to the Encyclopaedia of Islam: 'Dar al-Islam ... is the whole territory in which the law of Islam prevails,', ${ }^{2}$ while dar al-harb are 'those countries where the Muslim law is not in force.' ${ }^{3}$ Traditional Islam considers any territory not under Shari'a rule to be dar al-harb. Although many mediaeval and contemporary scholars mention the legal division between the two abodes, the partition of the world was not a device employed by the Prophet or his Companions, and the Qur'an and Sunna are both silent on this issue, as are the scholars of Islam's first century. ${ }^{4}$ It is striking to note that although the belief that the world is divided into two has been commonly referred to by scholars throughout Islamic history, there is actually no legal basis for this in Shari'a. ${ }^{5}$

2 A. Abel, 'Dar al-Islam', in B. Lewis, Ch. Pellat \& J. Schacht (eds.), Encyclopaedia of Islam, vol. 2 (2nd ed., Leiden: Brill, 1965), 127.

3 Ibid., p. 126.

4 Several hadith mention the 'land of war' and the 'land of Islam', such as Jami' At-Tirmidhi: '....when the Imam has left the land of war, and returned to the land of Islam, he applies the punishment on those deserving'. See Al-Tirmidhi, English Translation of Jami 'At-Tirmidhi, translated by Abu Khaliyl, vol. 3 (Riyadh: DarusSalam, 2007) number 1450 at 236 . However, these terms were not originally used in any legal sense to divide the world between Islamic and non-Islamic regions, but rather were geographical divisions.

5 The Qur'an does refer to paradise, however, as in these two examples: 'For them [a people who take heed] will be the home of peace (Paradise) with their Lord' (Qur'an 6:127); and 'Allah calls to the home of peace and guides whom He wills to a Straight Path' (Qur'an 10:25). Paradise is considered to be a place where believers can practice their religion safely and live peacefully. The mediaeval Islamic scholar Ibn Kathir defined it as somewhere where 
It is clear therefore, that the notion of a world divided into two abodes, dar al-Islam and dar al-harb, was one that was developed some time after the Prophet's era. By the mediaeval Islamic period however, this division was clear; the partition between dar al-Islam and dar al-harb and those that live there, that is, between the lands of belief and unbelief and between Muslims and non-Muslims, was one that deeply impacted all aspects of life. Scholars based this division on social and legal arguments, and there were very different approaches to dar al-Islam and dar al-harb. In the mediaeval period dar al-harb was considered to be a forbidden region, and scholars held that travel beyond the Muslim frontier was not allowed. Ibn Abi Zayd al-Qayrawani (d. $386 \mathrm{AH} / 996 \mathrm{CE}$ ), a 1oth CE Maliki scholar in the Tunisian city of Qarawan, stated that 'Trading to the territory of the enemy and to the land of the Sudan is disapproved'. ${ }^{6} \mathrm{Al}-$ Mawardi (d. $448 \mathrm{AH} / 1058 \mathrm{CE}$ ) stated that if someone left dar al-Islam for dar al-harb he would forfeit his wealth, but that this would be restored to him if he returned to Islam. ${ }^{7}$

The division of the world by mediaeval scholars into zones of peace and of war was thus born of mediaeval understandings of the regions beyond the Muslim world and of the need for security, both of which became bound into the development of the concept of, and calls for, jihad. The historical context was crucial. The Muslim partition of the world they knew was deeply affected by the permanent state of war during the Islamic expansion of the mediaeval period.

Khaled Abou El Fadl argues that the permanent war footing between Muslims and non-Muslims had little to do with religion; rather, it was because many jurists held that non-Muslims posed a potential threat to Muslims as people, rather than to Islam as a religion. ${ }^{8}$ Even the term used to denote the border between dar al-Islam and dar al-harb implied this sense of unease regarding what lay beyond; the word thughur (pl.thaghr) was used, whose basic

'residents are safe due to their access to the straight path' and Muslims are 'free from defects and miseries'. See, Ibn Kathīr, al-Misḅāh al-munīrfì tahdhïb tafsīr Ibn Kathïr = Tafsir ibn Kathir, abridged by a group of scholars under the supervision of Safi-ur-Rahman al-Mubarakpuri, vol. 3 (Riyadh: Darussalam, 2000), 466, 590.

6 Ibn Abi Zayd al-Qayrawani (d. 386AH/996CE) cited in Corpus of Early Arabic Sources for West African History, translated by J.F.P. Hopkins, edited and annotated by N. Levtzion \& J.F. Hopkins (Cambridge: Cambridge University Press, 1981), 55 .

7 Al-Mawardi, Al-Ahkam as-Sultaniyyah: The Laws of Islamic Governance, translated by Asadullah Yate (London: Ta-Ha Publishers, 1996), 85.

8 Khaled Abou El Fadl, The Great Theft: Wrestling Islam from the Extremists (New York: Harper San Francisco, 2007), 226. 
meaning is 'gap, breach, opening.' ${ }^{9}$ Moreover, it was seen as a zone, rather than a boundary line. According to Brauer, this partly reflects the sense of a frontier in all those areas where Muslim territory met non-Muslim, often Christian, areas. ${ }^{10}$ In the mediaeval age the territories beyond dar al-Islam were viewed as being inherently dangerous, and the no-man's land between, the thughur, was seen as a zone to be utilised as the first line of defence. Bauer notes that it was studded with small fortresses that served both as protection for the adjacent Muslim territories and as bases for raids into "heathen" regions. ${ }^{11}$

Muslim and non-Muslim lands were seen quite differently in the mediaeval Islamic world. Muslims were constantly threatened, or felt threatened, by enemies beyond dar al-Islam. The Muslim world was surrounded by a variety of heathen states and polities, and from early in Islamic history there was a strong shared consciousness that the community of believers was faced on many fronts by dar al-harb, 'the land of war of the Quranically mandated permanent state of Holy War.' ${ }^{12}$ Jurists developed a theory which portrayed the world beyond Islam as 'dar al-harb', and proclaimed conflict, in part the result of Islamic expansionism, to be the default relationship between it and the Muslim world. ${ }^{13}$

Despite the fact that the Qur'an and Sunna do not divide the world into Islamic countries and war, and that this division is seen as a mediaeval innovation, many scholars trace the notion of dar al-harb back to the Prophet's time, citing the historical experience of Islam during his era. There are two key factors in the origins of the Islamic division of the world, namely the hijra (migration) of the Prophet and his followers from Mecca to Medina, and the treaty between the Companions of the Prophet [the Rightly Guided Caliphs] and the unbelievers. The hijra to Medina is crucial because after migrating the Prophet formed a religious group or society (umma) whose sense of difference contributed to the emergence of the concept that the world was divided into believers and non-believers. Brauer notes that from the earliest days of Islam in Mecca and Medina:

9 C.E. Bosworth, 'Al-Thughur', in: P. J. Bearman, Th. Bianquis, C. E. Bosworth, E. van Donzel \& W. P. Heinrichs (eds.), Encyclopaedia of Islam, vol. 10 (Leiden: Brill, 2000), 446. Ralph W. Brauer, 'Boundaries and Frontiers in Medieval Muslim Geography', Transactions of the American Philosophical Society 85(6) (1995): 1-73, 16-18.

11 Ibid., p. 15 .

12 Ibid., p. 11.

13 Gamal M. Badr, 'A Survey of Islamic International Law', American Society of International Law: Proceedings of the Annual Meeting 76 (1982): 56-61, 56-57. 
'dar al-Islam was governed by the Prophet's preaching and the Qur'anic command that all true believers should be brothers inhabiting one single 'umma under a single imam, and hence there could not exist any internal frontiers. ${ }^{14}$

This structure of a single political unit under one ruler continued under the Rightly-Guided Caliphs and even through to the rule of the Umayyad caliphs from Damascus, albeit with some reservations. ${ }^{15}$

\subsection{Hijra}

The Islamic division of the world along the lines of belief has been significantly influenced by the concept of hijra and by the migrations undertaken by the Prophet and by his followers in the years thereafter. Although hijra is commonly translated into English as "migration", it has a broader meaning and usage. Not only does it signify physical migration from one place to another, it also carries the theological sense of escaping from evil and of 'separation from one's family and clan and attachment to others.' ${ }^{16}$ According to the Encyclopaedia of Islam: '.... hidjra [ hijra] properly does not mean "fight" as it has been traditionally translated but connotes primarily the breaking of the ties of kinship or association.' ${ }^{17}$

Calls for hijra have been made throughout Islamic history by scholars or leaders seeking to move from areas of non-Muslim rule to those already ruled by Muslims, or to those which a successful migration could convert to the Islamic cause. ${ }^{18} \mathrm{~A}$ justification for such a migration away from the land of a heathen ruler can be seen in the mediaeval Islamic textbook, Reliance of the

\footnotetext{
14 Brauer, supra note 10 at 8.

15 Ibid., p. 8.

16 W. Montgomery Watt, Muhammad: Prophet and Statesman (London: Oxford University Press, 1961), 91.

17 W. Montgomery Watt, 'Hidjra', in: B. Lewis, V.L. Ménage, Ch. Pellat \& J. Schacht (eds.), Encyclopaedia of Islam, vol. 3 (Leiden: Brill, 1971), 366.

18 Although calls to hijra were mainly made to Muslims, migrations were also undertaken by unbelievers who accepted invitations to migrate to Muslim lands. Furthermore, migration was used to spread the Islamic religion to new areas. Umar II (d. 101AH/720CE) wrote that 'we open it [land] up to whosoever may emigrate of the Bedouin, and who sells his cattle and removes from his Bedouin abode (dar a'rabiyyatihi) to the abode of emigration [dar al hijra] and to do battle with our foe'. See H.A.R. Gibb, 'The Fiscal Rescript of 'Umar II', Arabica 2(1) (1955): 1-16, 3-4.
} 
Traveller, which noted that Muslims whose ruler has left Islam or abandoned Shari'a should either rise up or migrate. ${ }^{19}$

The meaning of hijra has constantly evolved, and even during the Prophet's own lifetime two forms of migration were recognised. The first form was simply for the purpose of escaping from persecution, as was the case in the very first hijra, made in 615 CE to Abyssinia. Migration was thus not initially to prove one's Muslim belief, and furthermore it was voluntary, and not obligatory. This first migration followed a recommendation by the Prophet; ${ }^{20}$ despite Abyssinia being a Christian kingdom and thus not dar al-Islam, the Prophet believed that his followers would be able to freely practice their religion there. The emigrants noted that the Abyssinians were 'in peace about our faith; we worshipped Allah and we were not hurt, nor we heard any word displeasing to us.. ${ }^{21}$

The second hijra, however, from Mecca to Medina, was both an escape from persecution and an attempt to establish an Islamic community in a new place. This hijra sought to dispense completely with any unwanted or unneeded customs, beliefs or ties based on blood or tribal affiliation from the pre-Islamic or Meccan eras, instead creating new relationships based on the religion of Islam. ${ }^{22}$ It was one of the pivotal events of Islamic history, and has been cited by scholars as the model migration from dar al-kufr to dar al-Islam. It was obligatory but was not simply seen as a move from persecution or to dar alhijra, but also as part of creating a new Islamic community. From this time on, many scholars have viewed migration from dar al-harb to dar al-Islam as being compulsory for all Muslims.

Many Qur'anic verses mention the Prophet's hijra; verse 4:97, for example, asks 'Was not the earth of Allah spacious enough for you to emigrate therein?' Ibn Kathir notes that this verse refers to those Muslims who chose to stay and live alongside non-believers, even though they could have migrated. ${ }^{23}$ Verse

19 Ahmad Ibn Naqib Al-Misri, Reliance of the Traveller: A Classic Manual of Islamic Sacred Law translated by Nu Ha Mim Keller (Dubai: Modern Printing Press, 1991), 640-641 (o25.3). Ibn Hishām, The Life of Muhammad: A Translation of Ishạq's Sìrat rasūl Allāh, with introduction and notes by A. Guillaume (New York: Oxford University Press, 1978), 146150; Mamar Ibn Rashid, The Expeditions: An Early Biography of Muhammad, edited and translated by Sean W. Anthony, foreword by M.A.S. Abdel Haleem (New York: New York University Press, 2014), 113; Al-Tabari, The History of Al-Tabari Vol. 6: Muhammad at Mecca, translated and annotated by W. Montgomery Watt and M.V. McDonald (New York: State University of New York Press, 1988), 98-101.

21 Ibn Hishām, supra note 20 at 146.

22 The Second hijra was recorded by Al-Tabari. See, Al-Tabari, supra note 5 at 139-152.

23 Ibn Kathir, supra note 6, vol. 2, at 559 . 
4:10o also touches on the obligation to migrate: '... whosoever leaves his home as an emigrant unto Allah and His Messenger, and death overtakes him, his reward is then surely incumbent upon Allah'. Ibn Abbas recorded that verse 4:100 was revealed regarding an old man from Mecca who died on the migration to Medina; both he and Ibn Kathir emphasised that anyone who begins the migration but dies on route can expect the same reward from God as Muslims who complete the journey. ${ }^{24}$

\subsection{Jihad}

As with hijra, jihad is a broad term that has evolved through the centuries of Islamic history and has been understood and interpreted in a multitude of ways. In contrast to the Prophet's understanding, in contemporary Islam it is most commonly translated as 'Holy War' or actual physical fighting against unbelievers. This is a scholarly interpretation, but not one drawn from the Qur'an - it is the construction of mediaeval scholars. However, despite the mediaeval and modern-day interpretation of jihad as implying war and physical struggle, jihad is also one of the most mystical concepts in Islam. It is seen as an expression of religion both inwardly and outwardly, and is considered to be 'a method of bringing religion into practice.' ${ }^{25}$ According to The Encyclopaedia of Islam it 'etymologically signifies an effort directed towards a determined objective ....an effort directed upon oneself for the attainment of moral and religious perfection. ${ }^{26}$ In Arabic, it implies patience and perseverance and is a call against evil temptation and lust. ${ }^{27}$ This is reflected in the Qur'anic position on jihad, which makes no mention of war. Although Allah ordered the Prophet to undertake jihad against disbelievers and hypocrites ('Strive hard against the disbelievers and the hypocrites' [Qur'an 9:73]), there was no specific mention of physical fighting. Both the Qur'an and Sunna view jihad as a struggle on behalf of God, and as a religious duty for all Muslims. The Qur'an calls on Muslims to 'strive hard and fight in the Cause of Allah' [Qur'an 61:11], and 'strive hard with your wealth and your lives in the Cause of Allah' [Qur'an 9:41]. Such efforts

24 Ibn Abbas, Tafsir Ibn 'Abbas: Great Commentaries on the Holy Qur'an, translated by Mokrane Guezzou (Amman: Royal Aal al-Bayt Institute for Islamic Thought, 2007), 99; ibid., p. 562 .

25 Ignaz Goldziher, Muslim Studies: (Muhammedanische Studien), edited by S.M. Stern, translated from the German by C.R. Barber and S.M. Stern, vol. 2 (London: George Allen \& Unwin, 1971), 354.

26 Emile Tyan, 'Djihād', in: Lewis et al. (eds.), Encyclopaedia of Islam, supra note 2 at 538.

27 Mostafa Fadel, "Islamic Law and Modern Life" (University of Utah, mimeographed lecture, 1964), 88-89. 
are considered to be a religious obligation or responsibility and a fundamental Islamic principle that, if followed, will lead to paradise. ${ }^{28}$ Similarly, when jihad is mentioned in hadith they do not explicitly reference physical fighting. In one hadith the Prophet was asked 'Which is the best deed?', to which he replied 'To believe in Allah and His Messenger', and then: 'To participate in Jihad in Allah's Cause'; ${ }^{29}$ there was no specific reference to war.

In the first century of Islam, jihad was thus simply a spiritual term; it implied peaceful truthfulness and personal struggle. Neither the Prophet himself nor the scholars who immediately followed him considered jihad to imply physical fighting against an enemy. The Prophet stated that "The best [form] of Jihãd is a just word spoken to an oppressive Sultan....[or]....an oppressive Amir ${ }^{30}$ 'Abd Allah ibn 'Umar (Abdullah ibn Umar; d. 74AH/693CE), son of the second Caliph 'Umar, noted: 'The greatest jihad and holy war is the battle against the soul, and the chief of all unbelievers is the soul. ${ }^{31} \mathrm{Ibn} \mathrm{Battal}$ (d. 449AH/1057CE), a Maliki scholar from Cordova, said: 'A man's struggle against himself is the most perfect jihad',32 while Ibn Qayyim (d. 751AH/ 1350CE) also emphasised this personal aspect

And because the best form of Jihad is speaking the truth in spite of the severest opposition, such as when one speaks it while he fears the power of another, the Messenger had an abundant share of that and he was the most perfect and complete among mankind in doing so. And since making Jihad against an enemy is secondary to Jihad of oneself, as the Prophet said: "The Mujahid is one who performs Jihad of his self in obedience to Allah'. Jihad of the self takes precedence. ${ }^{33}$

28 'Alī ibn Abī Talib, Nahjul Balagha: Sermons, Letters, and Sayings of Imam Ali (Qum: Ansariyan, 1981), 105 .

29 Muhammad ibn Ismail al-Bukhari, The Translation of Meanings of Sahih Al-Bukhari, translated by Muhammad Muhsin Khan, vol. 2 (Riyadh: Darussalam, 1997), number. 1519, at 345 .

30 Abu Dawud, English Translation of Sunan Abu Dawud, translated by Nasiruddin al-Khattab, vol. 4 (Riyadh: Darussalam, 2008), number 4344, at 542.

31 Julie Scott Meisami (editor, translator), The Sea of Precious Virtues (Bahr al-Fava'id): A Medieval Islamic Mirror for Princes (Salt Lake City: University of Utah Press, 1991), 16.

32 Ibn Hajar al Asqalani, Selections from Fath Al-Bari, translated by Adal Hakim Murad (Cambridge: Muslim Academic Trust, 2000), 16-17. [Italic added].

33 Ibn Al-Qayyim, Provisions for the Hereafter (Mukhtasar Zad Al-Ma'ad), abridged by Imam Muhammad Ibn Abdul Wahhab At-Tamimi (London: Darussalam, 2003), 246. 
Jihad can also embody the fulfilment of religious obligation. Abdul-Rahman ibn Abi Bakr (d. 44AH/666 CE), a Companion of the Prophet, viewed going to the mosque to pray as a form of jihad: 'Someone who goes to the mosque in the morning or the afternoon with no intention of going anywhere else, either to learn good or teach it, is like someone who does jihad ....34

When 'Aishah, one of the Prophet's wives, asked him for permission to join jihad, the Prophet replied 'Your Jihad is (the performance of) Hajj [pilgrimage] ${ }^{35}$ The Qur'anic views on jihad are broad. Qur'an 22:78 exhorts Muslims to '... strive hard [jihad] in Allah's Cause as you ought to strive ... So perform As-Salat [worship God], give Zakat [tax] and hold fast to Allah ....'

\section{3}

Hijra and Jihad

Even at a relatively early stage in Islamic history, the meaning and usage of both hijra and jihad had evolved and were no longer those of the Prophet's time: terms referring to the migration of the Prophet and to a personal spiritual struggle on behalf of God. This section examines how the Islamic dogmas of hijra and jihad developed from their original usage in the first century of Islam through to their employment by modern extremist groups such as Daesh.

There are many examples of Muslim territories becoming dar al-kufr (or harb), prompting leaders or scholars to call for Muslims to migrate to dar alIslam or dar al-hijra. Over the centuries, scholars and others elaborated the meaning of hijra to encompass a 'decisive repudiation of unbelief'. ${ }^{36} \mathrm{Abu}$ Ubayd (d. $224 \mathrm{AH} / 838 \mathrm{CE}$ ), a prominent hadith master in Islam's early years, argued that emigration (hijra) itself was what distinguished believers from unbelievers. ${ }^{37}$ However, after the Prophet's time, hijra was not only used in this 'defensive' sense but also as a tool with which to launch military jihad and take over land or convert it from dar al-harb to dar al-Islam. Similarly, the meaning of jihad gradually evolved from a fulfilment of religious obligations to physical

34 Imam Malik, Al-Muwatta, compiled by Yahya ibn Yahya al-Laythi, translated by 'A'isha 'Abdarahman at-Tarjumana and Ya'qub Johnson, editor-in-chief Idris Mears (Norwich: Diwan Press, 1982), 70 (9.18.56).

35 Al-Bukhari, supra note 29, vol. 4, number 2875 at 89 .

36 Roger Webster, 'Hijra and the Dissemination of Wahhabi Doctrine in Saudi Arabia', in Ian Richard Netton (ed.), Golden Roads: Migration, Pilgrimage and Travel in Medieval and Modern Islam (Richmond: Curzon Press, 1993), 11.

37 Abū 'Ubayd al-Qāsim ibn Sallām, The Book of Revenue-Kitab al-Amwāl, translated by Imran Ahsan Khan Nyazee, introduction by Ibrahim M. Oweiss (Reading: Garnet, 2002), 216. 
fighting in a holy war against Islam's enemies. The original sense of jihad was supplemented by a new meaning, namely one of military activity or actual physical fighting.

The Qur'an uses the term qital (fighting), and not jihad (striving hard), to refer to warfare. ${ }^{38}$ During the Prophet's era, jihad was clearly seen as a form of spiritual war, with the term qital being used to denote physical warfare. Abou El Fadl notes that ' $[\mathrm{e}]$ very reference in the Qur'an to qital is restricted and limited by particular conditions; but exhortations to jihad, like the references to justice or truth, are absolute and unconditional'. ${ }^{39}$ The Qur'an only allows qital, or actual physical fighting, for self-defence, while jihad is seen as striving or fighting for Allah's cause. Qital is thus restricted in its application, whereas jihad can be interpreted very widely to cover both mental/spiritual and physical activities. However, the two terms became increasingly conflated after the Prophet's time. Afsaruddin notes that 'after the first/eighth century, the notion of jihad was reduced in juristic and administrative literature increasingly often to just physical combat, thus becoming practically synonymous with qital (fighting) ${ }^{\prime}{ }^{40}$ The differences between qital and jihad became blurred during the mediaeval period, and ultimately it simply disappeared.

\subsection{The Historical Experience of Hijra and Jihad}

After the second migration from Mecca to Medina, and the resultant division of the world into Islamic and non-Islamic zones, the meaning of hijra changed. From this time on, the most common reason for hijra from a land of unbelief or war to one of belief was a change in a ruler's belief. Throughout Islamic history there have been scholars and extremist groups who have maintained that certain Muslim rulers should not be considered to be Muslims, and that therefore their lands have become dar al-kufr or dar al-harb.

This represented a crucial break with the Qur'an and Sunna, neither of which define any form of boundary between dar al-Islam and dar al-harb (or kufr). This idea that even territories ruled by a self-declared Muslim can be treated as non-Muslim, and the related notion that the world can therefore be divided into zones of belief and unbelief, can be traced back to the 7 th century CE Khawarij sect. They held that all territories were dar al-kufr until conquered for (their particular understanding of) Islam. ${ }^{41}$ Territories could switch between

\footnotetext{
$38 \quad$ Abou El Fadl, supra note 8, at 223.

39 Ibid., p. 223.

40 Asma Afsaruddin, 'Qital', in Oliver Leaman (ed.), The Qur'an: An Encyclopedia (London: Routledge, 2006), 520.

41 Ahmad Ibn Taymiyyah, Fatawa Ibn Taymiyyah, vol. 19 (Maktabat al Ma'arif n.d.), 73.
} 
these two states of belief depending on the religious affiliation of their rulers. If a ruler or his people turned against Allah or sinned, hijra from his land and jihad against it become obligatory. ${ }^{42}$

The possibility of dar al-Islam becoming dar al-harb has been reiterated by many scholars through the centuries. For example, Ibn Taymiyyah argued that this could happen if Islamic law was not enacted. Similarly, Shāh 'Abdul 'Azīz (1746-1824), an Islamic scholar in 19th century British India, argued in a fatwa that there were three ways that dar al-Islam could become dar al-harb: prohibition of Islamic rules, introduction of infidel rules, or protection rights not being honoured. ${ }^{43}$ An example of dar-al Islam changing to dar al-kufr (or harb) is that of Sokoto, Nigeria. In 1903, Nigeria fell to the British, leading the Sokotan Caliph (Muhammadu Attahiru; d. $1903 \mathrm{CE}$ ) to declare that Sokoto was no longer part of dar al-Islam. ${ }^{44}$

The obligation to move to Muslim realms has also been repeated by scholars throughout history, particularly during periods of invasion by unbelievers or foreign powers. During the Mongol invasion in the 13th century CE, Ibn Taymiyyah called on all Muslims to permanently migrate from dar alharb (in this case, areas ruled by the Mongols), as he held that Muslims can only live in lands regulated by Shari'a. ${ }^{45}$ Similarly, Ahmad Al-Wansharishi (d. 914AH/1508CE), a 15th-16th century North-African Maliki jurist, issued a fatwa regarding a Muslim who chose to remain in Marbella in southern Spain after its re-conquest by Christian "unbelievers". He declared that Muslims residing in a country ruled by heathens can never be free from (Christian) contamination, as they will inevitably be in constant contact with them, and that they should leave immediately for one that is ruled by Muslims. ${ }^{46}$

\subsection{Jihad and Hijra}

Declarations of jihad are often made together with calls for hijra. This is unsurprising, as migrations and calls for them are more frequent during periods of war. Both are considered by certain scholars and rulers to be religious

42 Muhammad Khalid Masud, 'The Obligation to Migrate: The Doctrine of Hijra in Islamic Law, in: Dale F. Eickelman \& James Piscatori (eds.), Muslim Travellers: Pilgrimage, Migration, and the Religious Imagination (London: Routledge, 1990), 34.

43 Saiyid Athar Abbas Rizvi, Shāh 'Abd al-'Azizz: Puritanism, Sectarian, Polemics and Jihād (Canberra: Ma'rifat Publishing, 1982), 228-229.

44 Basheer M. Nafi, 'Fatwa and War: On the Allegiance of the American Muslim Soldiers in the Aftermath of September 11', Islamic Law and Society 11(1) (2004): 78-116, 87.

45 Ibn Taymiyyah cited in Denise Aigle, Mongol Empire between Myth and Reality: Studies in Anthropological History (Leiden: Brill, 2014), 273.

46 L. P. Harvey, Islamic Spain 1250 to 1500 (Chicago: University of Chicago Press, 1990), 56-57. 
obligations for all Muslims, and several Qur'anic passages refer to them together. Verse 8:72, for example, mentions '... those who believed, and emigrated and strove hard [jihad] and fought with their property and their lives in the Cause of Allah ..... The same verse also states that those who have not undertaken hijra are not protected until they have done so. Similarly, Qur'an 3:195 refers to '.... those who emigrated and were driven out from their homes, and suffered harm in My Cause, and who fought, and were killed (in My Cause)...'.

The link between hijra and jihad is seen throughout Islamic history and can be traced back to the second migration, the Prophet's hijra from Mecca to Medina. In the following years migration became a means of expanding Islamic rule, with Mohammed's successors calling on Muslims to emigrate to garrison towns (amsar) and other locations in the dar al-hijra (abode of emigration). The second Caliph 'Umar was the first to develop the concept of hijra in this way. He stressed that emigration to garrison towns would help those believers already living there, and encouraged it by noting that 'The booty [ fay'] belongs to the people of the newly established garrison towns (amsar) and to those who joined them, gave them assistance and stayed with them: ${ }^{47}$

This was a clear evolution from the earlier use of hijra. The Prophet's migration to Medina was for self-defence and not for expanding Islam's territory, but the second Caliph 'Umar explicitly linked the two by viewing the destinations of Muslim migrations as potential bases for further expansion: 'Establish for the Muslims a place where they can migrate (and settle) (dar hijrah) [dar alhijra] and from which they can wage holy war. Do not place a great river (bahr) between me and the Muslims.'48

The connection between hijra and jihad can also be seen in the process of founding the Fatimid Caliphate. Abu 'Abdullah al-Shi'i (d. 298AH/911CE), an Ismaili $d a$ i (religious leader) in the 1oth century $\mathrm{CE}$, ordered all his followers to move to Tazrut after he had conquered it, as he considered it to be dar al-hijra. Believers from across the entire region moved to Tazrut and then joined the jihad to further expand his territory. ${ }^{49}$

Another example of the combination of hijra and jihad in the establishment of Islamic rule was the Almoravid movement of the 11th century CE, founded

47 Al-Tabari, The History of Al-Tabari Vol. 12; The Battle of al-Qādisiyah and the Conquest of Syria and Palestine, translated and annotated by Yohanan Friedmann (Albany: State University of New York Press, 1992), 203.

48 Ibid., p. 143.

49 Ibn Hayyūn, Founding the Fatimid State: The Rise of an Early Islamic Empire, annotated English translation of al-Qādi al-Nu'mān's Iftitāh al-Da'wah by Hamid Haji (London: I.B. Tauris in association with the Institute of Ismaili Studies, 2006), 89-90, 96. 
by Ibn Yasin (d. 451AH/1059CE). He had observed un-Islamic practices in Sanhaja (Morocco), such as men taking more than four wives, and therefore started to 'teach them religion and to explain the Law and the Sunna'.50 When he realised the difficulty he faced in teaching Islam and religious obligations to the people of Sanhaja, he undertook a hijra to an island with his seven companions. ${ }^{51}$ His Islamic community grew there to the point where he could call upon his followers and disciples, the murabitun or Almoravids (a thousand Sanhaja nobles), to make jihad or Holy War on those Sanhaja tribes who opposed them. ${ }^{52}$

A far more recent example is that of Usman dan Fodio (d. $1817 \mathrm{CE}$ ), the founder of the Sokoto Caliphate in Nigeria. Fodio's tutor, Shaykh Jibril (Jibril ibn 'Umar), had tried to reform Hausland's Muslim rulers and had written a polemic in which he criticised them for altering or abandoning the Sharia and thus for being unbelievers. ${ }^{53}$ Fodio called for a hijra to Gudu in Sokoto state, and for a jihad to overthrow non-Islamic customs and to establish Muslim law. ${ }^{54}$ He stressed that migration remained an obligation for Muslims, that jihad was closely connected to hijra and that the concept of dar al-Islam needed to be re-defined. ${ }^{55}$ All of Fodio's views were directed by his belief that his homeland, Hausland in Nigeria, was dominated by a corrupt ruler, Sarkin Gobir Nafata (the Sultan of Gobir, Yunfa dan Nafata (d.1808)). ${ }^{56}$ Fodio criticised the Sultan for practising paganism and being a polytheist; his jihad was one of 'truth against falsehood' and was aimed at purifying religion and 'putting an end to evil practices'. ${ }^{57}$ He saw jihad as an obligation, as a country ruled by heathens or polytheists was no longer dar al-Islam, it was dar al-kufr.

5o Ibn Abi Zar (d. 715AH/1315CE), cited in Corpus of Early Arabic Sources, supra note 6, at 239.

51 Ibid., p. 240; Jamil M. Abun-Nasr, A History of the Maghrib (London: Cambridge University Press, 1971), 93; Ivan Hrbek (ed.), General History of Africa III: A frica from the Seventh to the Eleventh Century (Paris: London: Berkeley: James Currey, 1992) 179.

52 Ibn Abi Zar, cited in Corpus of Early Arabic Sources, supra note 6, at 240.

53 A.D.H. Bivar \& M. Hiskett, 'The Arabic Literature of Nigeria to 1804: A Provisional Account', Bulletin of the School of Oriental and African Studies, University of London 25(1-3) (1962): 104-148, 141-143.

54 Nana Asma'u, Collected Works of Nana Asma'u, Daughter of Usman dan Fodiyo, 1793-1864, edited by Jean Boyd and Beverly B. Mack (East Lansing: Michigan State University Press, 1997), 135-136.

55 Masud, supra note 42 at 38.

56 Muhammad Bello \& E. J. Arnett, The Rise of the Sokoto Fulani, being a paraphrase and in some parts a translation of the Infaku'l Maisuri of Sultan Mohammed Bello by E.J. Arnett (Kano: Emirate Printing Department, 1922), 47-48.

Ibid., p. 63 . 
Another connection between jihad and hijra can be seen in Abu Ubayd's argument that believers who have joined the jihad are to be afforded the same legal protection and status as Muslims living in Muhajirun land [dar al-Islam]; in other words, he classed these two concepts as being equivalent for some purposes. The practical effect of this for Abu Ubayd was that in certain circumstances hijra was actually not obligatory, for if a believer had joined jihad he was excused from performing hijra. ${ }^{58}$

These historical examples illustrate the close links between jihad and hijra and show that some scholars consider both to be obligatory for Muslims, even being seen as proof of one's belief (iman). Ibn Qayyim, citing Qur'an 2:218, ${ }^{59}$ stated that 'Jihad is not complete without Hijrah, nor are Hijrah and Jihad complete without faith and belief'.60

\subsection{Military Jihad}

Jihad is a collective obligation ( fard al-kifaya), which means that the duty is incumbent on all Muslims; however, as Reliance of the Traveller notes, 'if someone undertakes it, then the obligation has been fulfilled and the sin and responsibility is lifted from the rest'.61 The jihad is actually only an individual (fard al'ayn) duty in two situations under traditional Islam. The first is if non-Muslims invade an Islamic nation, in which case it is an individual obligation upon all to attempt to repel the invaders. The second situation concerns those fighting in a battle line, when running away is forbidden. ${ }^{62}$ Finally, it is worth noting that jihad, in its physical warfare sense, was traditionally subject to other limitations. A debtor could not embark on holy war without his creditors' permission, while those with living parents needed their permission to join jihad. ${ }^{63}$

The above historical examples indicate that jihad was indeed interpreted by mediaeval scholars as actual physical fighting, and that as Crone argues: 'In classical law jihad is missionary warfare.' ${ }^{64}$ This understanding of jihad can be readily understood from mediaeval Islamic textbooks and other scholarly

58 Abū 'Ubayd, supra note 37, at 218.

59 (Qur'an 2:218): 'Verily, those who have believed, and those who have emigrated (for Allah's Religion) and have striven hard in the Way of Allah, all these hope for Allah's Mercy. And Allah is Oft-Forgiving, Most-Merciful'.

6o Ibn Qayyim, supra note 33 at 250.

61 Ibn Naqib Al-Misri, Reliance of the Traveller, supra note 19, at 33 (c3.2).

62 'Ali ibn Tahir al-Sulami, The Book of the Jihad of 'Ali ibn Tahir al-Sulami (d. 1106), text, translation and commentary by Niall Christie (Farnham, Surrey: Ashgate, 2015), 209.

63 The Sea of Precious Virtue, supra note 31 at 28.

64 Patricia Crone, God's Rule: Government and Islam (New York: Columbia University Press, 2004), 364 . 
works. The fourteenth century Reliance of the Traveller, for example, notes that 'Jihad means to war against non-Muslims'.65 Ibn Taymiyyah (d. 728AH/1328CE) considered physical warfare to be essential for jihad, and cited verse 8:39 to explain its aim: 'And fight them [disbelievers] until there is no more fitnah [sedition/temptation] and the religion will all be for Allah alone'.66 Some mediaeval scholars argued that jihad should be used for converting unbelievers to Islam. Ibn Khaldûn (d. 808AH/1406cE) stressed its obligatory nature: 'In the Muslim community, the holy war is a religious duty, because of the universalism of the (Muslim) mission and (the obligation to) convert everybody to Islam either by persuasion or by force. 67

In mediaeval times, military jihad against unbelievers was a ruler's duty; he was required to 'make jihad against those who resist Islam after having been called to it until they submit or accept to live as a protected dhimmi (unbeliever)-community'68 Indeed, the earlier mediaeval scholar Al-Farabi (d. 339AH/950CE) noted that one of the conditions of power was to undertake jihad: 'he [the ruler] should be able to go on the holy war (jihad).'69

Although the Prophet did not introduce military jihad, some have sought to justify such actions by referring to his actions against unbelievers. Some have argued that the treatment of such people actually changed during the Prophet's lifetime from mere warnings to actual physical fighting. In the fourteenth century, Ibn Qayyim had noted that during the Meccan period the Prophet was not allowed to fight anyone, while after the move to Medina he was permitted to fight those who fought him, and then finally was allowed to instigate hostilities against those disbelievers who had no covenant with Islam. ${ }^{70}$

Certain scholars argue that the Prophet himself made references to military jihad and that the Qur'an prescribes it. For example, Ibn Qayyim argued that 'Allah commanded his followers to forgive non-believers, and to wait until they were strong enough to fight.'71 In the 2oth century, Sayyid Qutb

65 Ibn Naqib Al-Misri, Reliance of the Traveller, supra note 19 at 599 (o9.o).

66 Ibn Taymiyyah, The Religious and Moral Doctrine of Jihaad (Birmingham: Maktabah al Ansaar Publications, 2001), 28.

67 Ibn Khaldûn, The Muqaddimah: An Introduction to History, translated from the Arabic by Franz Rosenthal, vol. 1 (Princeton, N.J.: Princeton University Press, 1980), 473.

68 Al-Mawardi, supra note 7 at 28 (italic added). Also see Ibn Naqib Al-Misri, Reliance of the Traveller, supra note 19, at 647 (o25.9).

69 Muhammad b. Muhammad al-Farabi, Fușūl al-Madanī (Aphorisms of the Statesman), edited with an English translation, introduction and notes by D.M. Dunlop (Cambridge: Cambridge University Press, 1961), 51.

70 Ibn Qayyim, supra note 33 at 340-341.

71 Ibid., p. 297. 
(d. 1386AH/1966CE) noted that Allah's order not to fight while in Mecca was only temporary. ${ }^{72}$

Certain scholars have sought to defend military jihad by pointing to certain subtle differences in the words used in Qur'anic verses revealed while the Prophet was in Mecca, as opposed to those revealed during the subsequent Medinan period. The Meccan verses make no mention of military activities against unbelievers; verse 29:69, for example, notes '... those who strive hard in Us (Our Cause), We will surely guide them to Our Paths'. Some point to this as proof that fighting was prohibited in the Meccan period. Al-Qurtubi (d. 671AH/ $1273 \mathrm{CE}$ ) argues that: 'There is no disagreement that fighting was forbidden before the Hijra by the words of Allah', highlighting Qur'an verse 41:34: 'Repeal the bad with something better', and other Meccan verses. ${ }^{73}$

Some scholars believe that the first verse to reference military jihad was Qur'an 22:39, ${ }^{74}$ which states that: 'Permission to fight is given to those who are fighting them .... Similarly, verse 2:190 allows Muslims to fight those who attack them: 'And fight in the Way of Allah those who fight you, but transgress not the limits. Truly, Allah likes not the transgressors'. They thus argue that military jihad is prescribed in the Qur'an and Sunna. Their arguments regarding jihad have provided the basis for the beliefs and actions of many modern extremist groups.

The evolution of the twin Islamic dogmas of hijra and jihad are crucial in understanding modern extremist groups. The shift in the meaning of jihad from spiritual 'fighting' to actual physical warfare against an enemy has profoundly affected the ways in which such groups operate. Dae'sh have used these terms in their attempts to establish an Islamic caliphate in Iraq and Syria. They consider all other rulers in Muslim majority states to be apostates. As with the Khawarij in the 7 th century $\mathrm{CE}$, they only consider their own land to be dar al-Islam, and

72 Sayyid Qutb, Milestones, with a forword [sic] by Ahmad Zaki Hammad (Indianapolis: American Trust Publication, 1990), 53; Sayyid Qutb, In the Shade of the Qur'ān = Fì ziläl al-Qur'ān, vol. 7 (Markfield: Islamic Foundation, 2003), 15 .

73 Al-Qurtubi, Tafsir al-Qurtubi: Classical Commentary of the Holy Qur'an, translated by Aisha Bewley, vol. 1 (London: Dar al-Taqwa, 2003), 490.

74 Abu Muhammad 'Abdullah Ibn Abi Zayd al-Qayrawani, A Madinan View: on the Sunnah, Courtesy, Wisdom and History, translated by Abdassamad Clarke (London: Ta-Ha, 1999), 142; Ibn Qayyim, supra note 33 at 298: Ibn Kathïr, supra note 5, vol. 6, at 582-583. 
view all other areas, even if nominally Islamic, as dar al-kufr. Whether Muslims can or cannot practice their religion or live safely in such 'heathen' lands is irrelevant to them. Their worldview allows for only two realms, one that is ruled by them and one that is not; there is 'no third camp present. ${ }^{75}$ One either subscribes to their model, beliefs and practices, or one belongs to the enemy camp of disbelief ( $k u f r)$ and hypocrisy, and is thus their enemy. ${ }^{76}$

Extremist groups today also make declarations of takfir (excommunication) against certain Muslim rulers, just as the Khawarij had done. Dae sh have made such declarations in order to start military jihads and change dar al-harb or kufr into dar al-Islam, an Islamic state. ${ }^{77}$

\subsection{Division of the World and Hijra Today}

As with the traditional Islamic approach to the division of the world, certain scholars argue that dar al-Islam by definition should be ruled by Shari'a, lest it become dar al-kufr or dar al-harb. Sayyid Qutb, notes that 'The main criterion in considering an area as a 'land of Islam' is whether Islamic law is implemented in it or not. ${ }^{\prime} 8$ The land can become dar al-kufr regardless of whether the majority of the population are Muslim or not, or whether the ruler is Muslim or not. ${ }^{79}$ Extremist groups believe that a Muslim should not live in dar al-kufr, viewing it as a sin. Like in Al-Wansharishi's 15th century CE fatwa, Dae'sh is critical of such Muslims. ${ }^{80}$ Other groups and scholars have also called for modern-day migrations. For example, Sayyid Qutb, argues that the requirement to migrate is as obligatory now as it ever was:

Once there is a place on earth, any place, where Islam rules and where one can feel secure declaring one's faith and fulfilling one's religious duties, then one must migrate in order to live under the banner of Islam and enjoy the sublime standard of life Islam affords. ${ }^{81}$

\footnotetext{
75 'The Return of the Khilafah' (Dabiq, issue 1, 2014), 10-11.

76 Ibid., p. 11.

77 See Mohamed Badar, Masaki Nagata \& Tiphanie Tueni, 'The Radical Application of the Islamist Concept of Takfir', Arab Law Quarterly 31(2) (2017): 134-162.

78 Sayyid Qutb, supra note 73, vol. 4, at 81.

79 Ibid., pp. 81-82.

$80 \quad$ 'Shariah Alone Will Rule Africa' (Dabiq, issue 9, 2015) 55-56. Interestingly, and as with Abu Hanifa (d. 150AH/772CE), Dae'sh state that punishment for hudud offences might not be applied in the land of Sham (Syria) because before Dae'sh invaded 'Shām was dārul-harb and ... hudüd should not be implemented therein!.

81 Sayyid Qutb, supra note 73, vol. 3, at 286.
} 
Besides certain Islamic scholars, contemporary extremist groups such as Boko Haram also issue calls for hijra. ${ }^{82}$ The most high profile recent case is again that of Dae'sh, who consider hijra to be a test for those Muslims living in dar al-kufr. ${ }^{83}$ Citing the words of the mediaeval jurists Ibn Qudāmah (d. 620AH/1223CE) and Al-Mawardi (d. 448AH/1058CE), ${ }^{84}$ Daesh continually reiterate their belief that hijra is an obligation for all Muslims, wherever they are in the world. They believe that hijra carried out by Muslims living in dar al-kufr is a statement of their belief, but in fact, their calls are fundamentally different from those of the Prophet or made by Fodio in the 19th century. These earlier calls were for the purpose of avoiding persecution by rulers and others, while Dae'sh believe that the mere act of living alongside unbelievers is a sin regardless of whether Muslims are being persecuted or not.

Dae'sh portray hijra as a 'chance to live under the shade of the Sharìa alone'. ${ }^{85}$ From their very beginnings, Dae'sh's goal has been to establish an Islamic state in the Middle East governed solely by Shari'a, along with the secondary aim of securing a base from which their sphere of control can be steadily expanded across the region and world. ${ }^{86}$ Their particular interpretation of Shari'a law holds that they are justified in proclaiming al-Baghdadi their leader (Caliph), in founding an Islamic state and in seeking to expand that state through war. ${ }^{87}$ Their use of hijra thus differs greatly from that of the Prophet.

\subsection{Jihad Today: Wars against Islamic Rulers}

The fundamental aim of Shari'a is to secure social stability. It prohibits fighting against rulers, and that is why Dae'sh's attempts to overthrow rulers in the name of God, and the calls by others to do the same elsewhere, are highly controversial from an Islamic law standpoint. Jihad against the rulers of one's own state, in other words civil war, is one of the biggest issues confronting Muslim society today. Abd al-Salam Faraj, whose work partly inspired the assassination of Egyptian President Sadat in 1981, noted in his pamphlet The Neglected Duty that the 'first battlefield for jihad is the extermination of these infidel leaders

82 The founder of Boko Haram, Mohammed Ali, called for a hijra from Maiduguri in Borno State to Kanama in Yobe state. See Oluwaseun Bamidele, 'Defeating Boko Haram Terrorism: Who is Winning this War?', Strife Journal (4) (2014): 45-51, 48.

83 'The Murtadd Brotherhood' (Dabiq, issue 14, 2016), 19.

84 'The Law of Allah or the Law of Men' (Dabiq, issue 10, 2015), 52.

85 'From Hypocrisy to Apostasy' (Dabiq, issue 7, 2015), 61-62.

86 'The Return of the Khilafah', supra note 75 at 8.

87 'From the Battle of Al-Ahzab to the War of Coalitions' (Dabiq, issue 11, 2015), 10. 
and to replace them by a complete Islamic Order'.88 Along with other modern extremist groups, Dae'sh consider military jihad against infidels or un-Islamic rulers to be a religious obligation for all Muslims.

Indeed, fighting un-Islamic rulers has been encouraged and justified by certain scholars and groups throughout Islamic history. The Khawarij sect, for example, considered the fourth Caliph Ali to be an apostate and called for war against him, while Ibn Taymiyyah considered the Mongol rulers of the 14th century CE to be un-Islamic and called for jihad against them. As the concept of jihad is closely related to the Islamic notion that the world is divided into dar al-Islam and dar al-harb, Muslim leaders have often made declarations of jihad against rulers of the latter areas i.e., dar al-harb, such as the Byzantine empire in the mediaeval period, to protect dar al-Islam from infidel invasion and for other reasons.

Jihad can also be used internally, as declarations of struggle against those Muslim rulers perceived to be non-believers. Abul Ala Maududi (d. 1399AH/ 1979CE) stated that "the objective of the Islamic "Jihad" is to eliminate the rule of an un-Islamic system and establish in its stead an Islamic system of state rule. ${ }^{89}$ This explains why calls for jihad are still being used in combination with hijra by contemporary extremist groups aiming to overthrow "infidel" rulers. Dae'sh, for example, note that 'Hijrah has been a pillar inherent to jihad, particularly in eras void of darul-Islam [dar al-Islam],, ${ }^{90}$ and that 'One first performs hijrah to the lands of jihād. ${ }^{91}$ For Dae'sh, jihad means physical warfare against infidel governments and other enemies, and encompasses the duty to perform hijra and to achieve shahadah (the basic statement of the Islamic faith: 'There is no god but Allah and Muhammad is the prophet of Allah'). In addition to pledging to protect the frontiers of their Islamic state, it is notable that Dae's $h$ 's call to jih ad requires their followers to acknowledge the leadership of Abu Bakr al-Baghdadi; the concept of jihad is thus clearly crucial to their ideology and agenda. $^{92}$

88 Appendix: translation of Muhammad Abd al-Salam Faraj's text entitled Al-Faridah alGha'ibah, 'The Neglected Duty', in Johannes J.G. Jansen, The Neglected Duty: the Creed of Sadat's Assassins and Islamic Resurgence in the Middle East (New York: Macmillan, 1986), $193(\$ 70)$.

89 Maulana Abul Ala Maududi, Jihad in Islam (Beirut: The Holy Koran Publishing House, 2006), 22.

$90 \quad$ 'The Return of the Khilafah', supra note 75 at 34.

91 'They Plot and Allah Plots' (Dabiq, issue 9, 2015), 13.

92 They have called upon Muslims to eradicate any shirk or heretical behaviour and customs and to unite behind the Caliph (al-Baghdadi) in jihad. They view hijra as an Islamic obligation and as the first step in establishing a caliphate. See, Mohamed Badar, "The Self-Declared 
However, Islam actually prohibits military jihad against a ruler in two ways. First, under Islamic law, bughāh (rebels) and muharibun (terrorists) are not treated the same way. Although bughäh literally means transgressors, to be a rebel is not in itself a crime under Islamic law. The four traditional schools of law have defined "rebels" in the Islamic context as a group of Muslims who are organised in order to fight a ruler and claim to have just cause $\left(t a^{\prime}\right.$ wil $\left.l\right)$ for their actions. ${ }^{93}$ Notably, the Islamic laws of rebellion (ahkām al-bughāh) enable both parties to such conflicts, the rebels and the state, to engage as equal partners in many respects. For example, it affords legal recognition to the rebels for any judgments they pass, providing they do not contradict Islamic law. ${ }^{94}$ However, Dae'sh are considered to be muharibun (terrorists), and not bughäh (rebels). Indeed, some have argued that modern uprisings and wars started by extremist groups against so-called 'un-Islamic' rulers can be considered to be hirabah. The Qur'an defines this Arabic term (which derives from a root meaning 'warfare' or 'combat'), as meaning waging war and causing corruption. ${ }^{95}$ Shaykh Tusi (d. $460 \mathrm{AH} / 1067 \mathrm{CE}$ ) noted that people who bear arms against the state and enter into armed conflict, whether in Muslim or non-Muslim territory, are known as muharib; they are to be punished by death under traditional Islamic law. ${ }^{96}$

The second way in which military jihad against a ruler is prohibited by Islam relates to the fact that the words and deeds of many of those scholars and groups who support such actions and issue calls for it directly contradict those of the Prophet, who expressly forbade wars against rulers. He stated that any rulers who came after him who did not follow his examples and ways, as outlined in the Sunna, should be obeyed 'even if your back is flogged and your

Islamic State (Da'esh) and Ius ad Bellum under Islamic International Law', Asian Yearbook for Human Rights and Humanitarian Law 1 (2017); 35-75.

93 A. Al-Dawoody, M. Badar \& N. Higgins, 'The Origins and Evolution of Islamic Law of Rebellion-Its Significance to the Current International Humanitarian Law Discourse', in: Ignacio de la Rasilla del Moral and Ayesha Shahid (eds.), The History of International Law and Islam (Leiden: Brill/Nijhoff, forthcoming).

94 Ibid.

95 Chrystie Flournoy Swiney, 'Hirabah', in John L. Esposito (ed.), The Oxford Encyclopedia of the Islamic World, vol. 2 (New York: Oxford University Press, 2009) 407.

96 Shaykh Tusi, Al-Nihayah: Concise Description of Islamic Law and Legal Opinions (alNihayah fi Mujarrad al-Figh wa al-Fatawa), translated by A. Ezzati (London: ICAs Press, 2008), 485 . 
wealth is taken'. ${ }^{97}$ The disunity of Muslim groups and social disorder were considered to be a greater evil than unjust rulers. Similarly, Ahmad ibn Hanbal (d. $241 \mathrm{AH} / 855 \mathrm{CE}$ ) stated that:

... bearing up under the rule of whatever government there is, just or unjust; believing that we should not take up arms against rulers, even oppressive ones; not holding anyone who professes the oneness of God to be an Ingrate [Kafir], even if he commits grave sin....98

The Prophet did not use jihad as a rallying cry for war or as a means to overthrow rulers but rather to seek peace with his neighbours, proclaiming: 'Leave the Ethiopians alone so long as they leave you alone, and leave the Turks alone so long as they leave [you] alone. ${ }^{99}$ Imam Malik (d. $179 \mathrm{AH} / 795 \mathrm{CE}$ ) noted that 'People continue to avoid an attack on them [the Ethiopians]', implying that this injunction seems to have held after the Prophet's time, at least for a certain period. ${ }^{100}$ Any physical fighting that occurred during the Prophet's time was simply self-defense on the part of the nascent Islamic society, and was for the protection of believers. Mahmūd Shaltūt (d. 1963), the Shaykh of Al-Azhar between 1958-1963, stated

the Messenger only fought those who fought him, and ... his fighting had no other aims than repelling oppression, warding off rebellion and aggression and putting an end to persecution for the sake of religion. ${ }^{101}$

97 Imam Muslim, Sahih Muslim, translated by Nasiruddin al-Khattab, vol. 5 (Riyadh: Darussalam, 2007), number. 4785, 181. See also, Al Bukhari, supra note 30, vol. 9, number 7143 at $162-163$.

98 Ibn al-Jawzi, Virtues of the Imam Ahmad ibn Hanbal, edited and translated by Michael Cooperson, vol. 1 (New York: New York University Press, 2013), 327.

99 Abu Dawud, supra note 30, vol. 4, number. 4302 at 518.

100 Ibn Rushd, The Distinguished Jurist's Primer: A Translation of Bidāyat Al-Mujtahid, translated by Imran Ahsan Khan Nyazee, reviewed by Muhammad Abdul Rauf, vol. 1 (Reading: Garnet Publishing, 1994), 455-456.

101 Rudolph Peters, Jihad in Medieval and Modern Islam: The Chapter on Jihad from Averroes' Legal Handbook "Bidāyat Al-Mudjtahid" and the Treatise "Koran and Fighting" by the Late Shaykh al-Azhar Mahmüd Shaltüt, translated and annotated by Rudolph Peters (Leiden: Brill, 1977), 75. Similarly, Abu-Zahra noted: 'The Prophet (P.B.U.H.) emigrated to Madina wherein started a new sort of jihad. It was to fight in defence of the newly established Muslim State, so as to repel the repeated aggressive attacks launched by the Unbelievers against the Faithful who had been still under the Unbeliever's control and to safeguard 
Islamic scholars have sought to classify what constitutes 'just' and 'un-just' war. Al-Farabi considered that a defensive war was a just war, for example to 'ward off an enemy who has come against the city'.102 An offensive war could also be classified as a just war in very limited situations, such as for the 'acquisition of a good for the people of the city'.103 All other wars were seen as unjust, such as if a ruler made war only for the purpose of conquest. ${ }^{104}$ Abu Zahra, a contemporary Islamic scholar, has argued that fighting is only permissible for self-protection and for defending one's faith and community. ${ }^{105}$ Dae'sh's calls for military jihad against rulers in order to establish a caliphate, therefore lack legitimacy under the Islamic just-war theory and are not allowed within Islam.

\subsection{The Status of Hijra in Shari'a after the Prophet's Time}

From a Shari'a point of view, Dae'sh's division of the world is legally controversial. In the modern context it is open to question whether hijra from dar al-kufr to dar al-Islam is an obligation for Muslims. There is debate regarding whether those Qur'anic verses that relate to hijra have been abrogated or not. ${ }^{106}$ Some mediaeval jurists held that hijra can be an obligation if Muslims are unable to freely practice their religion. For example, Al-Nawawi (d. 676AH/1277CE) stated that if a Muslim could practice his religion, hijra was merely a recommendation, but if he was deprived of this, then hijra become an obligation. ${ }^{107}$ Similarly, Al-Wansharishi noted in a fatwa that the requirement to migrate for those whose land is occupied by tyrants ends only for those unable to migrate;

them against being forced to renounce their faith'. See, Muhammad Abu Zahra, 'The Jihad (Striving)', in Academy of Islamic Research, The Fourth Conference of the Academy of Islamic Research: Rajab 1388 September 1968 (Cairo: Al Azhar Academy of Islamic Research, 1970), 65-66.

102 Al-Farabi, supra note 69 at 57 (no. 63).

103 Ibid.

104 Ibid.

105 Abu Zahra, supra note 101 at 52.

106 Al-Shāfi'ì (d. 204AH/820CE) noted that 'To "abrogate" means to cancel an obligation'. See Muhammad ibn Idrīs al-Shāfi'ì, The Epistle on Legal Theory, edited and translated by Joseph E. Lowry (New York: New York University, 2013). Richard Bell explained that the doctrine of abrogation (naskh) was supported by the concept that 'certain commands to the Muslims in the Qur'an were only of temporary application, and that when circumstances changed they were abrogated or replaced by others. See, Richard Bell, Bell's Introduction to the Qur'an, completely revised and enlarged by W. Montgomery Watt (Edinburgh: Edinburgh University Press, 1970), 87-88.

107 Al-Nawawi, Minhaj et Talibin: A Manual of Muhammadan law, translated into English from the French edition of L.W.C. Van Den Berg by E.C. Howard (London: W. Thacker \& Co., 1914), 463 . 
all others must leave. ${ }^{108}$ Moreover, certain academics and groups argue that the obligation to undertake hijra still stands today because of the Prophet's statement that: 'The hijra does not cease as long as the unbelievers are to be fought'.109

However, other scholars believe that those Qur'anic verses that mention hijra have been abrogated, and therefore that any obligation to undertake hijra has ended. Both Abu Ubayd and Ibn Khaldûn argued that the Prophet's statement that ' $[\mathrm{t}$ ] here is no emigration after the conquest of Makka [Mecca]', meant there was no longer any obligation to perform hijra. ${ }^{110}$ It should be noted that the purpose of the Prophet's hijra and of those who came after were very different; this is the main reason for the topic being so controversial. The Prophet based his calls to his followers to migrate on Allah's instructions to him. As discussed earlier, they were for the purpose of protecting his believers (in the case of the first hijra, to the Christian kingdom of Abyssinia), and for establishing a new Islamic community or umma (as in the second hijra, from Mecca to Medina). The Prophet ordered these migrations for safety and security, and not because dar al-Islam had become dar al-harb. In the case of the first migration, this was not to an Islamic country, but to Abyssinia, which was simply a place where Muslims could freely practice their religion. ${ }^{111}$

All hijra after the Prophet's time, and hence after the first two migrations, were based on interpretations by scholars. Despite the arguments offered by some scholars and groups, it seems clear that there is no legal basis in Shari'a for these hijra. They differ from the first two migrations because to varying degrees, they all seem to have been politically motivated. The hijra to garrison towns developed and led by the second Caliph 'Umar, for example, were far from being straightforward religious obligations. Crone argues that at this time a dar al-hijra was 'simply an armed camp or mobilization centre to which one went to fight the infidels whoever and wherever they might be'; if an individual then chose to abandon the military life, the hijra would also come to an end.12

The 15th century experience of hijra in Islamic Spain was similarly far from being a purely religious migration; given the context, it was not possible to

108 Appendix B, 'Al- Wansharishi's 'Asna al-matajir', in al-Mi'yar al-mu'rid, in Alan Verskin, Islamic Law and the Crisis of the Reconquista: the Debate on the Status of Muslim Communities in Christendom (Leiden: Brill, 2015), 147.

109 Abū 'Ubayd, supra note 37 at 218.

110 Ibid., p. 222; see also, Ibn Khaldûn, supra note 67, vol. 1, at 255-256.

111 Ibn Hisham, Sirat Ibn Hisham: Biography of the Prophet, abridged by 'Abdus-Salam M. Harun (Cairo: Al-Falah Foundation, 2000), 56.

112 Patricia Crone, 'The First-Century Concept of "Hiğra", Arabica 41(3) (1994): 352-387, 367. 
replicate the Prophet's hijra from Mecca to Medina. Abou El Fadl argues that the fatwa issued by Al-Wansharishi in the 15th century was heavily influenced by the social and political conditions prevailing at the time, and was not based on previous legal thought. He therefore concludes that the fatwa was inevitably a product of the intensity of Christian/Islamic rivalry, and that the deep sense of humiliation that Al-Wansharishi felt is evident in his use of language. ${ }^{113}$ Nevertheless, although Al-Wansharishi's call for hijra has been much criticised, it is worth noting that the Muslim population in Granada declined due to Muslim emigration to North Africa. ${ }^{114}$

Usman dan Fodio's nineteenth-century call for hijra was also an attempt to replicate the Prophet's hijra, but as with Al-Wansharishi four centuries earlier, Fodio's call to migrate was made under very different circumstances from those prevailing during the Prophet's time. Although both the Prophet's and Fodio's followers were facing persecution, the legality of Fodio's hijra has been questioned. His hijra was mainly based on his belief that the Qur'anic obligation to undertake hijra still held. In addition, it was strongly affected by the political situation at the time. Doi argues that Fodio's hijra was more political than religious; it helped to maintain the 'faith, confidence and cohesion' of popular political movements engaged in the struggle against the British occupiers, and was actually a 'political struggle in the name of God.'115

Only the Prophet's hijra can be fully recognised as valid, and the legitimacy of all other hijra throughout Islamic history can be questioned. Therefore, Dae'sh's calls for hijra to test one's belief and establish an Islamic caliphate are not legitimate from a Shari'a perspective.

\subsection{Takfir and Military Jihad}

Ibn Qayyim argued that jihad can take four forms: against the self (nafs), against Satan, against disbelievers and hypocrites, and finally against perpetrators of injustice, evil deeds and religious innovations. ${ }^{116}$ Jihads of the third type, against hypocrites, have often been made against rulers who have been judged to be false Muslims. Calls for military jihad and hijra against such rulers are typically made after declarations of takfir have been issued against them. A

\footnotetext{
113 Khaled Abou El Fadl, 'Islamic Law and Muslim Minorities: The Juristic Discourse on Muslim Minorities from the Second/Eighth to the Eleventh/Seventeenth Centuries', Islamic Law and Society 1(2) (1994): 141-187, 155 .

114 David Coleman, Creating Christian Granada: Society \& Religious Culture in an Old-World Frontier City, 1492-160o (Ithaca: Cornell University Press, 2003), 16.

115 'Abdurrahman I. Doi, Islam in Nigeria (Zaria: Gaskiya Corp, 1984), 50.

116 Ibn Qayyim, supra note 33 at 249-250.
} 
takfir is a pronouncement that a particular Muslim or Muslims are unbelievers (kafir). The practice of making such a declaration in its raw and unvarnished form consists of declaring a person's religious belief (iman) as impure or as false and wrong. As such, it is an institutional act of religious censure used to deprive a Muslim of their Islamic status; in short, it is excommunication. ${ }^{117}$

Takfir have always been closely intertwined with both military jihad and hijra (from dar al-harb to dar al-Islam). The concept originated in the 7 th century CE and has been the main theoretical device used by extremist groups and scholars throughout the whole of Islamic history. The first takfir were issued with reference to the rebellious Khawarij sect at some point after the Prophet's time: 'Whoever rebelled against the legitimate imam [ruler] accepted by the people is called a Kharijite [Khawarij].118 As with Dae'sh, the Khawarij believed that they were the only true Muslims and that all others were unbelievers. ${ }^{119}$ The Khawarij rebelled after the battle of Siffin ( $657 \mathrm{CE}$ ), objecting to the Fourth Caliph 'Ali's arbitration with Mu'awiya (founder of the Umayyad Dynasty of the Caliphate (d. 6oAH/68ocE ). ${ }^{120}$ They argued that 'Ali had followed human, not divine, judgment; his action was clearly kufr, and they thus declared a takfir upon 'Ali and his fellow arbiters. ${ }^{121}$ The Khawarij believed that 'Judgment belong [s] to God alone',122 and contended that anyone doing otherwise should be punished by death. ${ }^{123}$ They argued that acts of disobedience to Allah can turn Muslims into kafirs (unbelievers) and lead to excommunication, even if they have not formally converted to another religion.

Such beliefs have been reiterated throughout Islamic history. Ibn Taymiyyah declared a takfir against the Mongol ruler of Syria and called for a jihad against him. He based his calls on the fact that the Mongols were combining their man-made Yasa code (Mongol customary law) with Sharia law, rather than

117 Ibrahim A. Karawan, 'Takfir', in John Esposito (ed.), The Oxford Encyclopaedia of the Modern Islamic World, vol. 5 (New York: Oxford University Press, 2009) 311.

118 Muhammad b. 'Abdul al-Karīm Shahrastānī, Muslim Sects and Divisions: The Section on Muslim Sects in Kitāb al-milal wa 'l-nihal, translated by A.K. Kazi and J.G. Flynn (London: Kegan Paul International, 1984), 98.

119 Mohamed Badar, Masaki Nagata and Tiphanie Tueni, 'The Radical Application of the Islamist Concept of Takfir', Arab Law Quarterly 31(2) (2017): 134-162.

120 Shahrastani, supra note 118 at 98-99.

121 Ibid., p. 99.

122 Ibid.

123 Al-Tabari, The History of al-Tabari, vol. 17: The First Civil War: From the Battle of Siffin to the Death of 'Alī A.D.656-661/A.H.36-4o (New York: State University of New York, 1996), 101. 
ruling using only Shari'a. Ibn Taymiyyah considered that false Muslims such as the Mongols were worse than unbelievers, as they still claimed to be Muslim. ${ }^{124}$

In mediaeval times, and indeed both before and since, military jihads have been conducted not only against non-Muslims but also against "false" Muslim rulers. Some have argued that campaigns against such Muslims are one of the most important types of jihad. Ibn Taymiyyah, noted that: "The most serious type of obligatory Jihaad [jihad] is the one against the unbelievers and against those who refuse to abide by certain prescription of the Shari'ah ... .' ${ }^{125}$ The theoretical background to this type of military jihad, that is, against false Muslims, is the concept of takfir or excommunication. In fact, modern hijra cannot be explained without reference to this concept.

Some contemporary extremist groups also make takfir declarations against rulers, and they consider the lands of such leaders to be dar al-kufr or harb. An early example of this was the 197os Egyptian group Al-Takfir wa'-Hijra, headed by Shukri Mustafa, who declared that the government and society as a whole was heretical (takfir al-mujtama'). ${ }^{126}$ They isolated themselves from mainstream society by forbidding state education or employment and only allowing internal marriage. ${ }^{127}$ Any Muslims that contravened these rules, even the Muslim Brotherhood, had declarations of takfir made against them and were classed as kafirs. ${ }^{128}$ As a result, all those residing outside the abode of alTakfir wa'l-Hijra were deemed to be infidels. ${ }^{129}$ Similarly, Dae'sh have declared that certain rulers should not be classed as Muslim and thus that their realms are dar al-kufr, although these rulers have not converted to another religion and are not being controlled by other (non-Muslim) rulers. Dae'sh have proclaimed that these leaders are false, simply because their countries are ruled by laws that are a combination of Shari'a and man-made legal systems, rather than by Shari'a alone.

Takfir has no legal basis in Shari'a and is actually prohibited by it. Although the term itself does not appear in the Qur'an, its position is clear: people do not have the right to excommunicate others, and calling a Muslim 'kafir' (unbeliever) is prohibited: '... say not to anyone who greets you (by embracing

\footnotetext{
124 Ibn Taymiyyah, supra note 66 at 9-10.

125 Ibid., pp. 33-34.

126 Umar Abdullah Kamel, Al-Khawarij al-Judud: Al-Mutatariffun [The Neo Khawari: The Extremists] (Cairo: Maktabat al-Turath al-Islamic, 1998), 131.

127 Ahmad Jali, Dirasah 'an al-Firaq fi Tarikh al-Muslimin: Al-Khawarij wa al-Shi'a (Riyadh: King Faisal Centre for Islamic Research and Studies, 1988), 109.

128 Ibid., p. 112.

129 Ibid., p. 116.
} 
Islam): "You are not a believer"' [Qur'an 4:94]. ${ }^{130}$ The Prophet warned Muslims '....not to declare a person a disbeliever for committing a sin, and not to expel him from Islam by an action.' ${ }^{131}$ Only God holds the right to decide whether one is a believer or not, and this decision can be made only in the hereafter.

Mediaeval Muslim scholars had not even anticipated that Muslims might be living in areas of dar al-harb under non-Muslim rulers; they focused on people who had converted to Islam while living in dar al-harb. ${ }^{132}$ This mediaeval understanding, namely that by definition Muslims can only live in dar al-Islam, is one of the reasons why calls for hijra have been made so often by certain scholars and groups.

Some mediaeval scholars and modern extremist groups have clearly prohibited Muslims from living in dar al-harb. Al-Wansharishi's 15th century fatwa noted that: 'Dwelling among the unbelievers, other than those who are protected and humbled peoples (ahlal-dhimma wa'l-saghar), is not permitted and is not allowed for so much as an hour of a day'.133 He argued that living in dar al-harb is prohibited 'because of the filth, dirt, and religious and worldly corruption which is ever-present'. ${ }^{134}$ Dae'sh have similarly criticised Muslims living in dar al-kufr, including those who have migrated to the West. According to Daesh these people have had their identities altered through exposure to Western unbelief and by living in mushrik (polytheist) lands, and that they have been negligent regarding their religious obligations. ${ }^{135}$

Both the Qur'an and Sunna are silent on the reclassification of dar alIslam as dar al-harb or kufr; this change was effected by later scholars, as was the construction and development of the concept of takfir. Mediaeval scholars however did discuss a variety of conditions that could lead to dar-alIslam becoming dar al-harb, and their 'traditional' approach was summarised by the twentieth-century scholar Muhammad al-Hamid (d. $1969 \mathrm{CE}$ ):

130 See also (Qur'an 6:108).

131 Abu Dawud, supra note 30, vol. 3, number. 2532, at 223.

132 See, Al-Tabari, Al-Tabari's Book of Jihad, a translation from the original Arabic with an introduction, commentary, and notes by Yasir S. Ibrahim, with a foreword by Yitzhak Nakash (Lewiston, N.Y.: Edwin Mellen Press, 2007), 169; Muhammad al-Shaybani, The Islamic Law of Nations: Shaybānìs Siyar, translated with an introduction, notes, and appendices by Majid Khadduri (Baltimore: John Hopkins Press, 1966), 138-140; Al-Tusi, supra note 96 at 217.

133 Verskin, supra note 108, Appendix A, 'Al- Wansharishi: On the Leader of the Muslims of Christian Marbella' at 138-139.

134 Ibid.

135 'The Murtadd Brotherhood', supra note 83 at 13. 
(a) that the security of Muslims through their leader no longer exists and the security of non-Muslims has taken its place; (b) that they have been surrounded on all sides such that it is impossible for the aid of Muslims to reach them; (c) and that not a single one of Islam's rules remains therein. ${ }^{136}$

The first two conditions are security-related, while condition (c) is a legal issue. However, even this last condition:'not a single one of Islam's rules remain therein [dar al-Islam]', cannot be said to apply to Muslim majority states today, as they clearly do employ certain Islamic rules. It is thus difficult to see how these three conditions could be satisfied without a country being occupied by a truly non-Muslim ruler. It should be noted here that the mediaeval understanding of how a region could change from dar al-Islam to dar al-harb was one that was highly dependent upon the particular circumstances pertaining at the time, namely a state of almost permanent war between Islam and its non-Islamic neighbours; all three conditions above reflect these circumstances.

For Islamic mediaeval scholars there was no reason or need to distinguish between physical and spiritual war, qital (fighting) and jihad, because the Muslim community was under continual attack from beyond. They needed to fight order to survive as a community and religion. As the three conditions outlined in mediaeval scholarship make clear, dar al-Islam becomes dar alharb when Muslim land is attacked and taken over by non-Muslims; it does not change through declarations of takfir.

5

\section{Conclusion}

None of the three concepts discussed in this article, namely military jihad, hijra (from dar al-harb or kufr to dar al-Islam) and takfir, are recognised by Shari'a. All the campaigns of military jihad and the hijra migrations from dar al-harb that were undertaken in the mediaeval period were direct responses to the particular circumstances pertaining at that time. There are no references in Shari'a that can be read as implying that jihad and hijra are obligatory for Muslims.

However, Daesh have reinterpreted hijra in the modern-day setting as a means of encouraging support for and realising the creation of an Islamic state or caliphate. Their call to perform hijra is based on their assertion that the world is dominated by man-made laws and un-Islamic rulers; their

136 Muhammad al-Hamid quoted in Ibn Naqib Al-Misri, Reliance of the Traveller, supra note 19, at 946 (w43.5). 
declarations of takfir against Muslim rulers are thus similar to those made by the Khawarij in the 7 th century CE against Caliph Ali, the fourth caliph. The Prophet's instructions to his followers to obey their rulers have been turned on their head by Dae'sh's call for "true" believers to disobey their Muslim leaders and launch military jihads. They do not treat jihad as a religious or spiritual concept in the sense that the Prophet did, but as a device with which they can call for and justify the killing of unbelievers and even fellow Muslims, even though they do not class those Muslims living beyond Daesh occupied countries as true believers anyway. These Islamic concepts have thus been dangerously re-interpreted by modern extremist groups.

They do not use hijra as a means to secure the survival of new Islamic communities, as the Prophet did, but in violent attempts to conquer non-Islamic territory or establish a new Islamic state. As with hijra, jihad is also being used to encourage terrorism. This bears no relationship to the Prophet's original intention or understanding of the term. In his era, the terms hijra and jihad were simply related to religious obligations, but Daesh use both to encourage and justify murder and war.

The question of whether there is any obligation for hijra in contemporary Islam is a controversial topic, but needless to say the political, social and religious conditions pertaining around the time of the Prophet's hijra are clearly not those we witness today. None of the hijra after the Prophet's time have been free from political motivation, and they cannot be justified in either religious or legal terms. Taking these various factors into account, there is surely no longer any obligation for emigration to Daesh-occupied territories in order to overthrow its ruler and establish an Islamic state.

Similarly, Dae'sh's division of the world into dar al-Islam (for which read land controlled by Dae'sh) and dar al-harb, seems difficult to justify given the lack of any legal basis in Sharia. Their claims form part of their overall political agenda rather than being based on religious arguments. There are no definitions of dar al-Islam or dar al-harb in the Qur'an or Sunna, and the separation of the world into zones of belief and non-belief was mainly the work of mediaeval scholars. The Qur'an only mentions the 'home of Paradise', a place where believers can live safely and practice their religion freely. Sadly, the difference between this vision and the reality of Daesh's practices could not be starker. ${ }^{137}$

137 For more on the claim made by Is that they are waging war under the banner of Islam, see Badar, 'Da'esh and Ius ad Bellum under Islamic International Law', supra note 92, 35-75. 